\title{
SALINITY INDUCED RESPONSES IN THE MARINE CYANOBACTERIUM Anacystis dimidiata
}

\section{RESPUESTAS INDUCIDAS POR SALINIDAD EN LA CIANOBACTERIA MARINA Anacystis dimidiata}

\author{
C.S.V. Ramachandra Rao \\ K. Krishnamurthy \\ Centre of Advanced Study in Marine Biology \\ Annamalai University \\ Parangipettai - 608502 \\ Tamilnadu, India
}

Recibido en diciembre de 1992; aceptado en agosto de 1993

\begin{abstract}
Growth and changes in biochemical composition were studied in the marine cyanobacterium Anacystis dimidiata, collected from a mangrove environment where salinities ranged from 5 to $40 \mathrm{ppt}$. The cyanobacterium showed optimum growth at $20 \mathrm{ppt}$ salinity. At low (5 ppt) and high $(40 \mathrm{ppt})$ salinities the growth was slow and chlorophyll $a$ and phycocyanin were low, whereas protein, free amino acid and free proline values were high in both low and high salinities.
\end{abstract}

\section{RESUMEN}

Se estudiaron el crecimiento y cambios en la composición bioquímica de la cianobacteria Anacystis dimidiata, procedente de un ambiente de manglar con salinidad de 5 a $40 \%$. La cianobacteria presentó crecimiento óptimo con $20 \%$ de salinidad. Con salinidades baja $(5 \%$ oo) y alta $(40 \%$ oo el crecimiento fue lento, y la clorofila $a$ y ficocianina fucron bajas, mientras que los valores de proteínas, aninoácidos libres y prolina libre resultaron altos, tanto en baja como en alta salinidad.

\section{INTRODUCTION}

Cyanobacteria occur in a varicty of environments ranging from cold waters to hot springs, and from freshwater to hypersaline environments (Horne and Commins, 1987; Dor and Hornoff, 1985; Wickstrom, 1984; Reynolds et al., 1987). Cyanobacteria living in coastal ecosystems such as mangroves and estuaries are subjected to changes in salinity, and adaptation to these changes is essential for survival in these environments. According to Krist (1979), salt adaptation is of fundamental importance for survival in brackishwater habitats and has priority over all other cellular processes.

Studies on the influence of salinity on both freshwater and marine cyanobacteria have been extensive. These short-term studies

\section{INTRODUCCION}

Las cianobacterias se encuentran en una variedad de ambientes que va de aguas frías a manantiales de agua caliente y de aguas dulces a medios hipersalinos (Horne y Commins, 1987; Dor y Hornoff, 1985; Wickstrom, 1984; Reynolds et al., 1987). Las cianobacterias que viven en los ecosistemas costeros como manglares y estuarios están sujetas a cambios de salinidad, y la adaptación a éstos es esencial para su supervivencia en tales ambientes. De acuerdo con Krist (1979), la adaptación a la sal es de importancia fundamental para sobrevivir en hábitat de aguas salobres y tiene prioridad sobre todos los otros procesos celulares.

Son extensos los estudios relativos a la influencia de la salinidad sobre las cianobacte- 
have been concerned mainly with the synthesis of organic solutes in response to salinity stress (Borowitzka et al., 1980; Mackay et al., 1983; Reed and Stewart, 1985; Erdmann et al., 1989, 1990; Hagemann et al., 1989; Hagemann and Wittenburg, 1989).

The objective of this study was to understand the salinity induced responses in Anacystis dimidiata, exposed to a range of salinities, in long-term experiments. $A$. dimidiata was subjected to the range of salinities that it would normally experience in the mangroves. Growth and biochemical changes were investigated.

\section{MATERIALS AND METHODS}

In the present study, Anacystis dimidiata Drouet and Daily was collected from the Pichavaram mangroves, India (Lat. 11029' N; Long. $79^{\circ} 49^{\prime} \mathrm{E}$ ), and purified in the laboratory. One millilitre of the freshly collected plankton sample containing $A$. dimidiata was inoculated in $M N$ medium (Waterbury, 1976). The salinity of the medium was adjusted to the salinity of the water from which the species were collected by adding distilled water to aged seawater of $34 \mathrm{ppt}$ salinity. Cultures were grown, illuminated with fluorescent tubes, at a photon flux density of $25.5 \mu$ moles $\mathrm{m}^{-2} \mathrm{~s}^{-1}$ and a 12 hour light and dark cycle. Temperature was maintained at $29 \pm 20 \mathrm{C}$. After 20 days, a portion of the mixed culture of cyanobacteria was streaked on agar plates containing $1.2 \%$ agar in $\mathrm{MN}$ medium. The isolated cells of $A$. dimidiata were restreaked on agar plates, and the procedure was repeated several times till the cells were bacteria-free

To determine the optimum salinity range, $\mathrm{MN}$ media of different salinities $(5,10$, 20,30 and $40 \mathrm{ppt}$ ) were prepared either by diluting the aged seawater of $34 \mathrm{ppt}$ or by adding $\mathrm{NaCl}$ to this seawater.

The cells growing in exponential phase were used for inoculation into $100-\mathrm{ml}$ flasks. Equal amounts of culture $(0.5 \mathrm{ml})$ were inoculated into flasks with medium of different salinities.

All cultures were harvested on day 20 of growth, after the light period. During the time of the harvest all the cultures were in the exponential phase of growth. rias, tanto de agua dulce como de mar. Estos estudios, de corto plazo, se han referido principalmente a la síntesis de solutos orgánicos como respuesta a la tensión por salinidad (Borowitzka et al., 1980; Mackay et al., 1983; Reed y Stewart, 1985; Erdmann et al., 1989, 1990; Hagemann et al., 1989; Hagemann y Wittenburg, 1989).

El objetivo de este estudio fue comprender las respuestas inducidas por la salinidad en Anacystis dimidiata expuesta a un determinado intervalo de salinidades, en experimentos a largo plazo. A. dimidiata se sujetó al intervalo de salinidades que experimentaría normalmente en los manglares. Se investigaron crecimiento y cambios bioquímicos.

\section{MATERIALES Y METODOS}

Para el presente estudio, se recolectó Anacystis dimidiata Drouet y Daily, de los manglares de Pichavaram, India (11029'latitud $\mathrm{N}$; 79049'longitud E), y se purificó en el laboratorio. Un mililitro de la muestra recién tomada de plancton con $A$. dimidiata se inoculó en medio MN (Waterbury, 1976). La salinidad del medio se ajustó a la del agua de la que fueron tomadas las especies, añadiendo agua destilada al agua envejecida de $34 \%$ de salinidad. Los cultivos en crecimiento se iluminaron con tubos fluorescentes a una densidad de flujo de fotones de $25.5 \mu$ moles $\mathrm{m}^{-2} \mathrm{~s}^{-1}$ y ciclos alternados de doce horas de luz y obscuridad. La temperatura se mantuvo a $29 \pm 2{ }^{\circ} \mathrm{C}$. Después de 20 días, una porción del cultivo mezclado de cianobacterias se estrió sobre placas que contenían $1.2 \%$ de agar en medio MN. Las células aisladas de $A$. dimidiata se reestriaron en placas de agar, y el procedimiento se repitió varias veces hasta que las células estuvieron libres de bacterias.

Para determinar el intervalo de salinidad óptima, se preparó medio $\mathrm{MN}$ con diferentes salinidades $(5,10,20,30$ y $40 \% / 00)$, diluyendo el agua de mar envejecida, de $34 \%$, o añadiendo $\mathrm{NaCl}$ a esa agua marina.

Las células en fase exponencial de crecimiento se utilizaron para inoculación en frascos de $100 \mathrm{ml}$. Se inocularon cantidades iguales de cultivo $(0.5 \mathrm{ml})$, en frascos con medio de diferentes salinidades.

Todos los cultivos se cosecharon en el vigésimo día de crecimiento, después del periodo de luz, y durante el tiempo de la 
Cell density of cyanobacteria in different salinities was measured by changes in the optical density at $600 \mathrm{~mm}$.

Biomass at different salinities was obtained as dry weight, placing the harvested cells in an oven at $60^{\circ} \mathrm{C}$ for 24 hours. The dried material was weighed in an electronic balance with $0.1 \mathrm{mg}$ accuracy.

Specific growth rate $(\mu)$, expressed as the percentage increase in dry weight per day, was calculated from the equation given by Mehta and Chauhan (1988).

Chlorophyll $a$ was measured by the method of Parsons et al. (1984), and phycobilins by the method of Bennett and Bogorad (1973). Protein concentration was estimated by the method of Lowry et al. (1951). Free amino acid (FAA) content was estimated using the method described by Moore and Stein (1954). Free proline concentration was estimated by the method of Bates et al. (1973).

\section{RESULTS}

Anacystis dimidiata had a five-day-long lag phase at 5, 10, 30 and $40 \mathrm{ppt}$ salinity, and a three-day-long lag phase at $20 \mathrm{ppt}$ (Fig. 1). Biomass was greatest at $20 \mathrm{ppt}$ and lowest at 5 ppt salinity. The specific growth rate was also highest at $20 \mathrm{ppt}$ and lowest at $5 \mathrm{ppt}$ salinity (Fig. 2).

Chlorophyll a content was highest at 30 ppt and lowest at 5 ppt salinity. Phycocyanin was highest at $20 \mathrm{ppt}$ and lowest at $40 \mathrm{ppt}$ salinity, whereas allophycocyanin concentration was highest at 10 and $30 \mathrm{ppt}$, and lowest at $20 \mathrm{ppt}$ salinity (Fig. 2).

Protein content of $A$. dimidiata was high at $5 \mathrm{ppt}$ and low at $20 \mathrm{ppt}$ salinity. Similarly, the FAA and free proline contents were highest and lowest at 5 and $20 \mathrm{ppt}$ salinity, respectively (Fig. 2).

\section{DISCUSSION}

The optimum salinity for growth of $A$. dimidiata was found to be $20 \mathrm{ppt}$. At this salinity the species had a short lag phase, whereas at lower and higher salinities the lag phase was relatively long. Dor and Hornoff (1985) reported that the duration of the lag phase in cultures depends on the salinity of the mediun. cosecha todos estuvieron en la fase exponencial de crecimiento.

La densidad celular de las cianobacterias en las diferentes salinidades se midió por cambios en la densidad óptica a $600 \mathrm{~mm}$.

La biomasa correspondiente a las diferentes salinidades se obtuvo como peso seco, colocando las células cosechadas en un horno a $60^{\circ} \mathrm{C}$ durante 24 horas. El material, una vez sacado, se pesó en una balanza electrónica con $0.1 \mathrm{mg}$ de precisión.

La tasa específica de crecimiento ( $\mu$ ), expresada como incremento del porcentaje en peso seco por día, se calculó a partir de la ecuación de Mehta y Chauhan (1988).

La clorofila $a$ se midió con el método de Parsons et al. (1984), y las ficobilinas con el de Bennett y Bogorad (1973). La concentración de proteína se estimó con el método de Lowry et al. (1951), y el contenido de aminoácidos libres, mediante el método descrito por Moore y Stein (1954). La concentración de prolina libre se determinó con el método de Bates et al. (1973).

\section{RESULTADOS}

A. dimidiata tuvo una fase de retardo de cinco días de duración, con $5,10,30$ y $40 \%$ oo de salinidad, y una fase de retardo de tres días de duración, con 20\% La mayor biomasa se obtuvo con $20 \%$ oo y la menor con 5\% de salinidad. La tasa específica de crecimiento también fue máxima con $20 \%$ y mínima con $5 \%$ de salinidad (Fig. 2).

Fl mayor contenido de clorofila a correspondió a $30 \%$ oo de salinidad y el menor a $5 \%$. La mayor ficocianina se obtuvo con $20 \%$ y la menor con $40 \%$ de salinidad, mientras que la mayor concentración de aloficocianina se logró con 10 y $30 \%$, y la menor con 20\% 100 (Fig. 2).

El contenido de proteína de $A$. dimidiala fue alto con $5 \%$ y bajo con $20 \% \%$ de salinidad. De manera similar, los contenidos mayor y menor de aminoácidos y prolina libres correspondieron a 5 y $20 \%$ de salinidad, respectivamente (Fig. 2).

\section{DISCUSION}

Se encontró que la salinidad óptima para el crecimiento de $A$. dimidiata es $20 \%$ oo. 


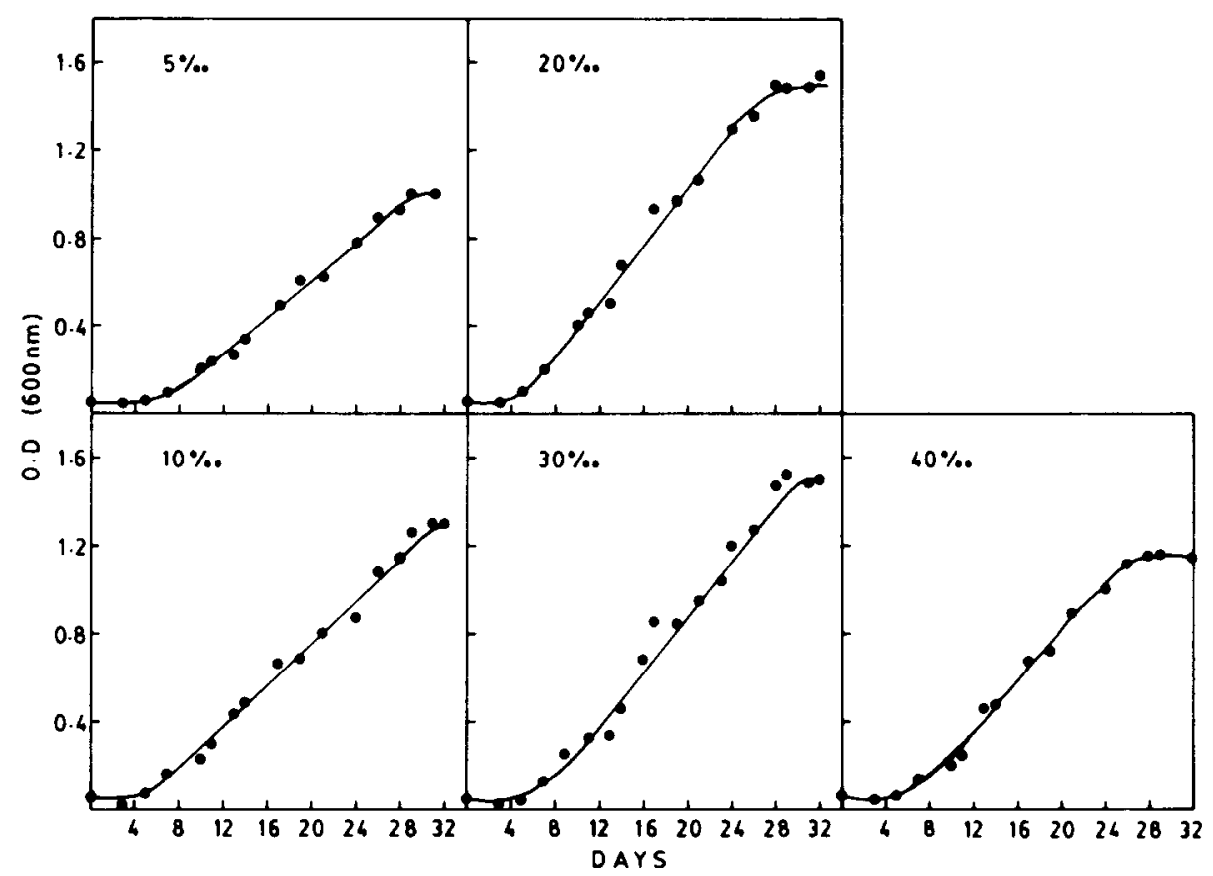

Figure 1. Growth curves of Anacystis dimidiata at five different salinities.

Figura 1. Curvas de crecimiento de Anacystis dimidiata con cinco salinidades diferentes

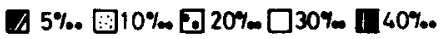

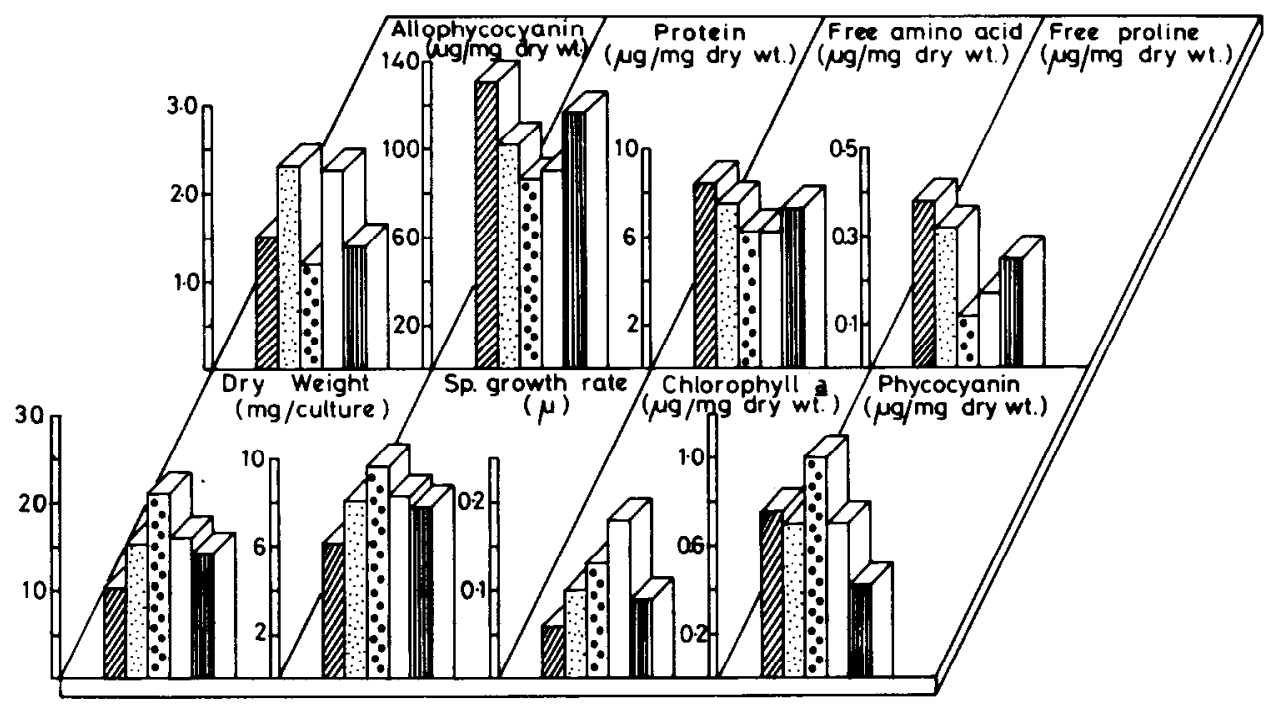

Figure 2. Effect of salinity on dry weight and biochemical constituents of Anacystis dimidiata after 20 days of inoculation.

Figura 2. Efecto de la salinidad sobre el peso seco y constituyentes bioquímicos de Anacystis dimidiata, después de 20 días de inoculación. 
Hagemann et al. (1989) stated that all influences on and changes of the cell metabolism are integrated in the specific growth rate. Hence, this parameter reflects best the complete adaptation of cells to different salinities. The highest specific growth rate and biomass observed at $20 \mathrm{ppt}$ salinity for $A$. dimidiata further revealed that this salinity is ideal for its optimum growth. At 5 and $40 \mathrm{ppt}$ salinity $A$. dimidiata had low specific growth rate and low biomass. This would indicate that this species was under stress.

The salinity stress affected cell chlorophyll $a$ content, which was lowest at the lowest salinity. Photosynthetic accessory pigments, like phycocyanin, were decreased most at the high $(40 \mathrm{ppt})$ salinity. The low chlorophyll $a$ content at 5 ppt and the low chlorophyll and phycocyanin content at $40 \mathrm{ppt}$ salinity might have led to low photosynthetic activity and resulted in low biomass in these salinities. Other cyanobacteria have been reported to show diminished photosynthesis under salt stress conditions (Blumwald and Tel-Or, 1984; Warr et al., 1985).

$A$. dimidiata growing in low $(5 \mathrm{ppt})$ and high (40 ppt) salinites showed increased protein as well as increased FAA and free proline content. The increase in the FAA and free proline content could be attributed to the synthesis of salt-induced-proteins under salt stress conditions. Apte and Bhagwat (1989) and Hagemann et al. (1990) reported enhanced synthesis of proteins under salt stress conditions. Increase in the protein content in $A$. dimidiata at 5 and $40 \mathrm{ppt}$ salinity could also be attributed to the activation of cellular metabolism to adapt to the stress condition. Vreeland (1987) reported that increased production of enzymes could be one strategy to overcome salt dependent enzyme inhibition. This could also be one reason for increased protein content in the cyanobacterium Anacystis dimidiata under salt stress conditions.

\section{ACKNOWLEDGEMENTS}

The authors thank the Director of C.A.S. in Marine Biology and the authorities of Annamalai University for the facilities provided. The first author thanks the Ministry of Environment and Forests, Government of
Con esta salinidad la especie tuvo una fase corta de retardo, mientras que con mayor o menor salinidad la fase de retardo fue relativamente larga. Dor y Hornoff (1985) señalaron que la duración de la fase de retardo en los cultivos depende de la salinidad del medio.

Hagemann et al. (1989) afirmaron que todos los cambios del metabolismo de la célula y las influencias ejercidas sobre el mismo se integran en la tasa específica de crecimiento. Por tanto, este parámetro es el que mejor refleja la completa adaptación de las células a diferentes salinidades. La mayor tasa específica de crecimiento y mayor biomasa observadas con $20 \%$ de salinidad para $A$. dimidiata confirmaron que esta salinidad es ideal para su crecimiento óptimo. Con 5 y $40 \%$ de salinidad, $A$. dimidiata tuvo baja tasa específica de crecimiento y baja biomasa. Esto indicaría que la especie estuvo bajo tensión.

La tensión causada por la salinidad tuvo efecto sobre el contenido celular de clorofila $a$, que fue el menor con la salinidad mínima. Los pigmentos accesorios fotosintéticos, como el contenido de ficocianina, tuvieron la mayor disminución con la salinidad máxima $(40 \% \%)$. El menor contenido de clorofila a con 5\% y los igualmente bajos contenidos de clorofila y ficocianina con $40 \%$ de salinidad pueden haber inducido baja actividad fotosintética y dar cono resultado baja biomasa con estas salinidades. Se ha informado de otras cianobacterias que muestran disminución de fotosintesis bajo condiciones de tensión salina (Blumwald y Tel-Or, 1984; Warr et al., 1985).

El crecimiento de $A$. dimidiata en baja $(5 \% / 00)$ y alta $(40 \%)$ salinidades mostró un incremento de proteína, así como de los contenidos de aminoácidos y prolina libres. El incremento de aminoácidos y prolina libres puede atribuirse a la sintesis de proteinas inducida por condiciones de tensión causada por sal. Apte y Bhagwat (1989) y Hagemann et al. (1990) indicaron que la sintesis de proteínas se acentúa bajo condiciones de tensión por sal. El aumento del contenido de proteína en $A$. dimidiata con 5 y $40 \%$ de salinidad puede también atribuirse a la activación del metabolismo celular para adaptarse a la condición de tensión. Vreeland (1987) señaló que el aumento de la producción de encimas podría ser una estrategia para superar la inhibición de encimas dependiente de la sal. Esta puede ser también una causa del aumen- 
India, for the financial assistance to carry out this work.

\section{REFERENCES}

Apte, S.K. and Bhagwat, A.A. (1989). Salinity-stress-induced proteins in two nitrogen-fixing Anabaena strains differentially tolerant to salt. J. Bacteriol., 171: 909-915.

Bates, L.C., Waldron, R.P. and Teare, I.D. (1973). Rapid determination of free proline in water stress studies. Plant and Soil, 39: 205

Bennett, A. and Bogorad, L. (1973). Complementary chromatic adaptation in a filamentous blue-green alga. J. Cell. Biol., 58: 419-435.

Blumwald, E. and Tel-Or, E. (1984). Salt adaptation of the cyanobacterium Synechococcus 6311 growing in a continuous culture (turbidostat). Plant Physiol., 74: 183-185.

Borowitzka, L.J., Demmerie,S., Mackay, M.A. and Norton, R.S. (1980). Carbon nuclear magnetic resonance study of osmoregulation in a blue-green alga. Science, 210: 650-651.

Dor, I. and Hornoff, M. (1985). Salinity temperature relations and morphotypes of a mixed population of coccoid cyanobacteria from a hot, hypersaline pond in Israel. P.S.Z.N.I. Mar. Ecol., 6: 13-25

Erdmann, N., Berg, C. and Hagemann, M. (1989). Missing salt adaptation of $\mathrm{Mi}$ crocystis fima (cyanobacterium) in the dark. Arch. Hydrobiol., 114:521-530.

Erdmann, N., Hagemann, M., Berg, C and Fulda, S. (1990). Basis of salt adaptation in cyanobacteria. Limnologica (Berlin), 20: 57-60.

Hagemann, M. and Whittenburg, E. (1989). Salt induced change in the RNA and DNA content of the cyanobacteria (blue-green algae) Synechocystis aquatilis and Microcystis fimma in batch and turbidostat cultures. Arch. Hydrobiol., 82: $381-391$

Hagemann, M., Erdmann, N. and Schiewer, U. (1989). Salt adaptation of the cyanobacteria Microcystis fimma and Synechocystis aquatilis in turbidostat cultures 1 steady state values. Arch. Hydrobiol., 82: 425-535. to del contenido de proteína en la cianobacteria $A$. dimidiata bajo condiciones de tensión por sal.

\section{AGRADECIMIENTOS}

Los autores agradecen, al Director del Centro de Estudios Avanzados en Biología Marina y a las autoridades de la Universidad Annamalai, las facilidades proporcionadas El primer autor agradece al Ministerio del Ambiente y Bosques, del Gobicrnode la India, la asistencia financiera para efectuar este trabajo.

Mora.

Traducido al español por Olivia Gómez

Hagemann, M., Woelfel, L. and Krucger, B. (1990). Alterations of protein synthesis in the cyanobacterium Synechocystis sp. Pcc 68013 after a salt shock. J. Cien. Microbiol., 136: 1393-1399.

Horne, A.J. and Commins, M.L. (1987) Macronutrient controls on nitrogen fixation in planktonic cyanobacterial populations. N.Z. J. Mar. Freshwat. Res., 21: 413-423.

Krish, G.O. (1979). Osmotische adaptation der marinen planktonalge platymonas subcordi formis (Hazen) - Ber Deutsch. Bot. Ges., 92: 31-42.

Lowry, O.H., Rosebrough, N.J., Farr, A.L. and Randall, R.J. (1951). Protein determination with the Folin Phenol reagent. J. Biol. Chem., 193: 265-275.

Mackay, M.A., Norton, R.S. and Borowitztia, L.J. (1983). Marine blue-green algae have a unique osmoregulatory system Mar. Biol., 73: 301-307.

Mehta, B.J. and Chauhan, N.D. (1988). Physiological and nutritional requirements of marine cyanobacterium Oscillatoria lactevirena (Crovan) Gom. Indian J. Mar. Sci., 17: 37-39.

Moore, S. and Stein, H. (1954). A modified ninhydrin reagent for the photometric determination of amino acids and related compounds. J. Biol. Chem., 211 : $907-913$.

Parsons, T.R., Maita, Y. and Lalli, C.M. (1984). A manual of chemical and biological methods for seawater analysis. Pergamon Press, Oxford, $173 \mathrm{pp}$. 
Ramachandra-Rao and Krishnamurthy: Salinity induced responses in Anacystis dimidiata

Reed, R.H. and Stewart, W.D.F. (1985). Osmotic adjustment and organic solute accumulation in unicellular cyanobacteria from freshwater and marine habitats. Mar. Biol., 88: 1-9.

Reynolds, C.S., Oliver, R.L. and Walsby, A.E. (1987). Cyanobacterial dominance; the role of buoyancy regulation in dynamic lake environments. N.Z. J. Mar. Freshwat. Res., 21: 379-390.

Tel-Or, E. (1980). Response of nitrogen fixing cyanobacteria to salt. Appl. Environ. Microbiol., 40: 689-693.
Vreeland, R.H. (1987). Mechanisms of halotolerance in microorganisms. CRC Crit. Rev. Microbiol., 14:311-356.

Warr, S.R.C., Reed, R.H., Chudek, J.A., Foster, R. and Stcwart, W.D.P. (1985). Osmotic adjustment in Spirulina platensis. Planta, 163: 424-429.

Wickstrom, C.E. (1984). Discovery and evidence of nitrogen fixation by thermophilic heterotrophs in hot springs. Current Microbiology, 10: 275-280. 